Int. J. Dev. Biol. 52: 551-559 (2008)

doi: $10.1387 / \mathrm{ijdb} .072531 \mathrm{av}$

\title{
The structure of sulfated polysaccharides ensures a carbohydrate-based mechanism for species recognition during sea urchin fertilization
}

\author{
ANA-CRISTINA E.S. VILELA-SILVA ${ }^{1,2}$, NORITAKA HIROHASHI ${ }^{4}$ and PAULO A.S. MOURÃO ${ }^{1,3, *}$ \\ ${ }^{1}$ Laboratório de Tecido Conjuntivo, Hospital Universitário Clementino Fraga Filho, ${ }^{2}$ Instituto de Ciências Biomédicas, ${ }^{3}$ Instituto de \\ Bioquímica Médica, Universidade Federal do Rio de Janeiro, Rio de Janeiro, RJ, Brazil and ${ }^{4}$ Genetic Counseling Course, Graduate \\ School of Humanities and Sciences, Ochanomizu University, Japan
}

\begin{abstract}
The evolution of barriers to inter-specific hybridization is a crucial step in the fertilization of free spawning marine invertebrates. In sea urchins, molecular recognition between sperm and egg ensures species recognition. Here we review the sulfated polysaccharide-based mechanism of sperm-egg recognition in this model organism. The jelly surrounding sea urchin eggs is not a simple accessory structure; it is molecularly complex and intimately involved in gamete recognition. It contains sulfated polysaccharides, sialoglycans and peptides. The sulfated polysaccharides have unique structures, composed of repetitive units of $\alpha$-L-fucose or $\alpha$-Lgalactose, which differ among species in the sulfation pattern and/or the position of the glycosidic linkage. The egg jelly sulfated polysaccharides show species-specificity in inducing the sperm acrosome reaction, which is regulated by the structure of the saccharide chain and its sulfation pattern. Other components of the egg jelly do not possess acrosome reaction inducing activity, but sialoglycans act in synergy with the sulfated polysaccharide, potentiating its activity. The system we describe establishes a new view of cell-cell interaction in the sea urchin model system. Here, structural changes in egg jelly polysaccharides modulate cell-cell recognition and speciesspecificity leading to exocytosis of the acrosome. Therefore, sulfated polysaccharides, in addition to their known functions as growth factors, coagulation factors and selectin binding partners, also function in fertilization. The differentiation of these molecules may play a role in sea urchin speciation.
\end{abstract}

KEY WORDS: acrosome reaction, sperm-egg recognition, cell recognition, sulfated fucan, speciation

\section{Introduction}

The contribution of complex glycoconjugates to cell-cell interaction have been extensively studied (Couchman et al., 2001; Selva and Perrimon, 2001). One of the biological phenomena used to study the role of carbohydrates in cellular interaction is fertilization, where the recognition mechanism between egg and sperm involves protein-carbohydrate interactions (Miller and Ax, 1990, Diekman, 2003).

Free-spawning echinoderms are excellent models to investigate molecular events involved in fertilization and to understand the evolutionary pathways that lead to speciation. Successful fertilization in these organisms depends upon overcoming a series of constraints even before the sperm makes contact with the egg. Males and females must synchronize gametogenesis and the timing of gamete release to the seawater. Once spawned, sperm must find and interact with a homologous egg, avoiding cross-fertilization with eggs of other species.

In this review we will focus on the molecular mechanisms that ensure species-specificity during sea urchin fertilization. Although different sea urchin species inhabit the same geographic region, eggs are mostly fertilized by homologous sperm. This speciesspecificity has required the development of precise regulatory mechanisms to keep species from interbreeding. Since there are no yet known environmental spawning signals related with species-specificity (Walker et al., 2001), the steps involved in establishing such barriers should be controlled at the level of gamete interaction. From this point of view, the sperm acrosome reaction

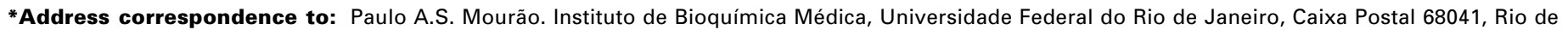
Janeiro, RJ, 21941-590, Brazil. Fax: +55-21-2562-2090. e-mail: pmourao@hucff.ufrj.br
} 
$(A R)$ is a crucial event.

In all animal sperm with acrosomes the AR is a necessary event for fertilization. When sperm approach the sea urchin egg, the egg jelly induces the sperm AR, which exposes the protein bindin at the tip of the acrosomal process of the sperm head. Only then can sperm attach to the egg and their plasma membrane fuse (Moy and Vacquier, 1979). In the sea urchin the sperm AR involves the exocytosis of the acrosomal vesicle and polymerization of actin to form a $\sim 1 \mu \mathrm{m}$ long acrosomal process. The AR was discovered in sea urchins, starfish and other marine invertebrates by J.C. Dan, working in Japan in the early 1950s (for a review see Hoshi et al., 1994). In the following decades, extensive studies
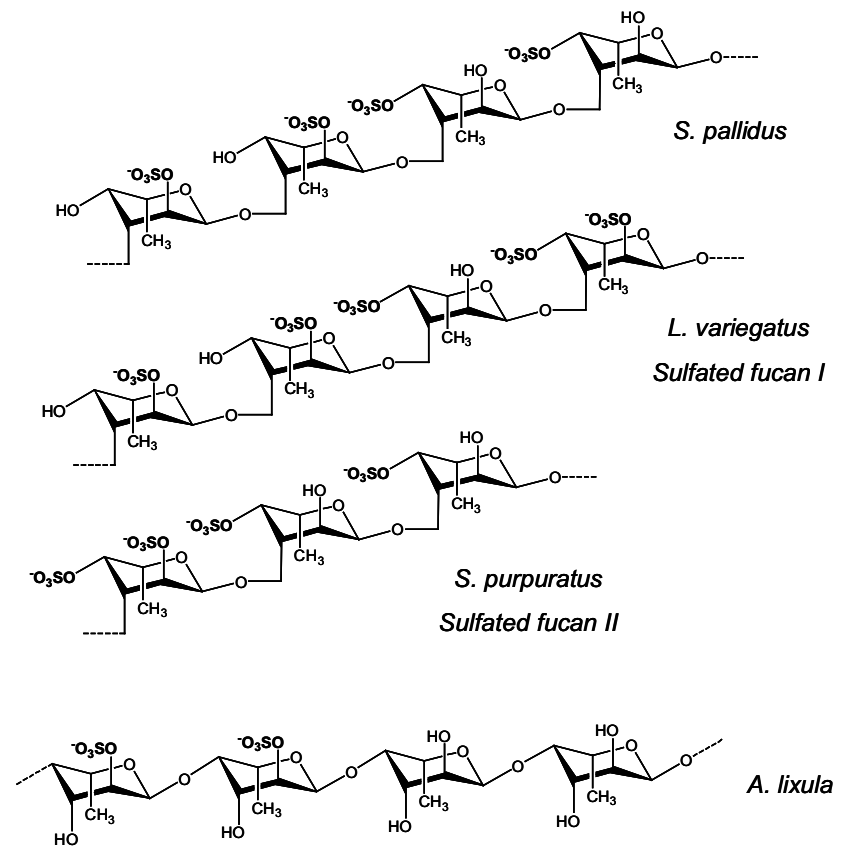

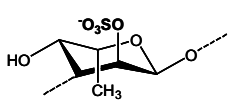

S. franciscanus

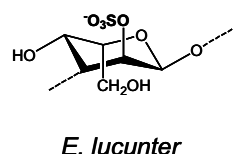

E. lucunter

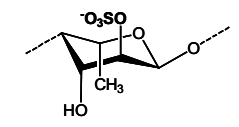

S. droebachiensis

Sulfated fucan II

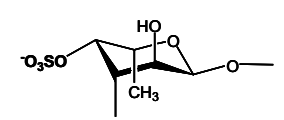

L. variegatus

Sulfated fucan II

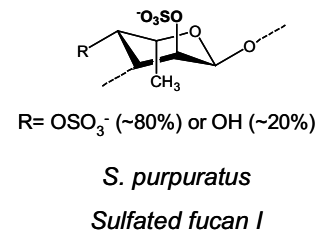

Sulfated fucan I
Fig. 1. Structures of sulfated polysaccharides from the egg jelly of various sea urchin species. Seven species have their sulfated polysaccharides structurally characterized. Some species may present two different isotypes of sulfated polysaccharides in their egg jelly. Except for E. lucunter, which contains a sulfated galactan, all other species present sulfated fucans. The specific pattern of sulfation and the position of the glycosidic linkage vary among the species. described the morphological and physiological changes that occur in the spermatozoa during the AR. The AR involves the influx of $\mathrm{Na}^{+}$and $\mathrm{Ca}^{2+}$ and the efflux of $\mathrm{H}^{+}$and $\mathrm{K}^{+}$through a variety of ion channels. These ion fluxes result in the increase of both intracellular calcium and $\mathrm{pH}$ (Darszon et al., 2007). A sustained increase of intracellular calcium is necessary for exocytosis of the acrosomal vesicle, while the increase of intracellular $\mathrm{pH}$ allows the polymerization of actin to form the acrosomal process and the exposure of bindin at the tip of the sperm head.

Previous work in the field assumed that in sea urchins, gametic mate "choice" during fertilization is controlled primarily, if not exclusively, by interaction of the sperm protein bindin and its egg receptor (Minor et al., 1991; Kamei and Glabe, 2003). However, SeGall and Lennarz (1979) suggested that the egg jelly (a gelatinous layer which surrounds sea urchin eggs) induces the $A R$ in a species-specific way. The egg jelly is composed of a mixture of sulfated polysaccharides, sialoglycans and peptides, but the identification of the specific molecule involved in the induction of the AR was not achieved until 1997, when it became clear that the sulfated polysaccharides are the inducers of the AR (Alves et al., 1997).

\section{Unique sulfated polysaccharides in sea urchin egg jelly}

The first evidence showing sulfated fucans in sea urchins was published $\sim 60$ years ago (Vasseur, 1948), but no structural study was performed on these compounds. Since 1994 we have begun a systematic analysis of the structures of the sulfated fucans (and also sulfated galactans) from different species of sea urchins.

Sulfated polysaccharides from sea urchin egg jelly have simple and unique structures, composed of unbranched, linear chains of $\alpha$-L-fucose or $\alpha$-L-galactose units, with well-defined repetitive units. The specific pattern of sulfation and the position of the glycosidic bond vary among sulfated fucans and sulfated galactans from different species (Fig. 1).

A simple sulfated fucan was identified in the egg jelly from the sea urchin $S$. franciscanus, which is a [3- $\alpha-\mathrm{L}-\mathrm{Fuc}-2\left(\mathrm{OSO}_{3}\right)$ 1] (Vilela-Silva et al., 1999), as well as a sulfated galactan in the egg jelly from $E$. Iucunter, a [3- $\left.\alpha-\mathrm{L}-\mathrm{Gal}-2\left(\mathrm{OSO}_{3}\right)-1\right]_{n}$ (Mulloy et al., 1994). Other sea urchins so far studied possess sulfated fucans with oligosaccharide repeating units, which vary among the different species according to the position of the glycosidic linkage and the sulfation site at 2- and 4-positions.

Sulfated fucans have already been found in marine brown algae as a constituent of the cell wall. But in contrast with the simple and ordered structures of the sea urchin polysaccharides, algal fucans have complex and heterogeneous structures. More recent studies have revealed the occurrence of repeating units in the sulfated fucans from some species of algae (Mourão, 2004; Berteau and Mulloy, 2003). Even in these cases, the presence of highly branched portions and the complex distributions of sulfate and acetyl groups highlight the heterogeneity of algal fucans in contrast with the echinoderm polysaccharides.

\section{Sulfated polysaccharides are species-specific induc- ers of the sea urchin sperm acrosome reaction}


Fig. 2. Structure of sulfated polysaccharides from sea urchin species that co-inhabit the Rio de Janeiro intertidal zone and their activity as inducers of the acrosome reaction. Modified from Alves et al., 1997.

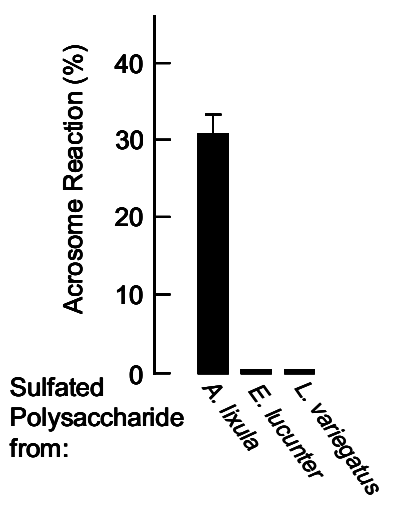

Sperm from:

(1) A. lixula

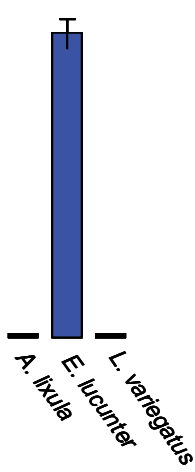

(2) E. lucunter

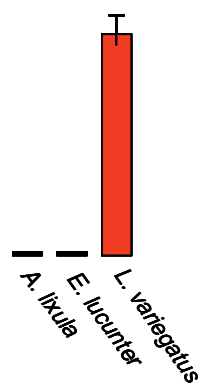

(3) L. variegatus

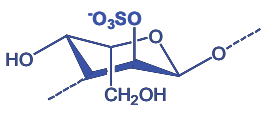

E. lucunter

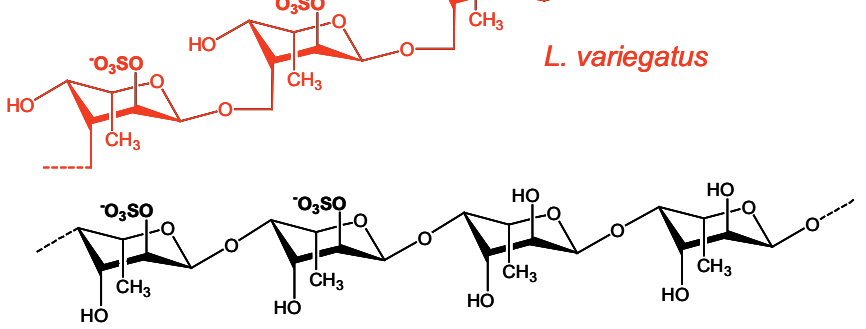

A. lixula

In an initial experiment to test whether sulfated polysaccharides from sea urchin egg jelly induce the $A R$, we incubated purified sulfated fucans and a sulfated galactan with homologous and heterologous sperm from species that co-inhabit the same area in Rio de Janeiro (sympatric species). We observed that the sulfated polysaccharides are species-specific inducers of the AR (Fig. 2).

The fact that the sulfated fucans are species-specific AR inducers was confirmed as the study was extended to the species Strongylocentrotus franciscanus and Strongylocentrotus purpuratus, both from the eastern north Pacific (Vilela-Silva et al., 1999; Hirohashi et al., 2002a). These species contain 3-linked fucans, which differ in the proportions of 2- and 4-sulfation. The pattern of sulfation is an important feature for recognition of fucans by sperm. As exemplified in Fig. 3, sperm from $S$. purpuratus were sensitive to homologous 4-sulfated fucan but not to heterologous 2-sulfated fucan (red symbols in Fig. 3). In these 3-linked sulfated fucans, the 2- and 4-positions are the only ones capable of sulfation. Oversulfation of the fucan from $S$. purpuratus did not change its responsiveness to homologous sperm, suggesting that increased 2-sulfates do not increase nor inhibit the biological activity in this species (blue symbols, Fig. 3). But, the sulfated fucan from $S$. franciscanus, which was ineffective on the $\mathcal{S}$. purpuratus sperm, induced the AR as did the homologous fucan after chemical oversulfation, because of increased 4-sulfation. Thus, the position of sulfation is crucial for AR inducing activity of the fucans of these Strongylocentrotus species, rather than the nonspecific charge density or sulfate content of the polysaccharide.

When sulfated fucans were tested at a concentration of 100 $\mu \mathrm{g}$ hexose $/ \mathrm{mL}$ in Strongylocentrotus species, we observed that the position of the glycosidic linkage (whether 3- or 4-linked) is the crucial structural requirement for the induction of the AR. Thus, a 2-sulfated, 4-linked fucan is inactive on $S$. franciscanus sperm, which recognize the homologous 2-sulfated, but 3linked fucan (Hirohashi et al., 2002a). Various 3-linked fucans, with variable sulfation at 2- and/or 4 positions are inactive on $\mathcal{S}$. droebachiensis, which has a 4-linked fucan (Fig. 4B).

Also curious, a 2-sulfated, 3-linked $\alpha$-L-galactan has the same potency as an AR inducer in sperm from $S$. franciscanus as the homologous 2-sulfated, 3-linked $\alpha$-L-fucan. This indicates that $S$. franciscanus sperm do not differentiate between

the $\mathrm{CH}_{2} \mathrm{OH}$ of L-galactose and the $\mathrm{CH}_{3}$ of L-fucose at position 6 . These two polysaccharides present the same sulfation pattern and glycosidic bond, differing only in the sugar moiety. Recently, comparison of these two sulfated polysaccharides regarding their solution conformation showed that they possess similar conformations and that the substitution pattern at C-5 (either $\mathrm{CH}_{2} \mathrm{OH}$ or $\mathrm{CH}_{3}$ ) has a small influence over the two pyranose conformational preferences of the monosaccharide residues (Becker et al., 2007).

The sulfated fucans of egg jelly have high molecular masses $(\geq 100 \mathrm{kDa})$ and this characteristic is crucial to induce the AR, possibly due to the effect of the polysaccharide on the sperm $\mathrm{Ca}^{2+}$ channels. When the sulfated fucan from $S$. purpuratus was subjected to mild acid hydrolysis, a decrease of its size produced a marked decrease in the ability to induce $\mathrm{Ca}^{2+}$ influx. After $5 \mathrm{~h}$ of mild hydrolysis, the sulfated fucan almost completely lost its capacity to induce the $A R$, but could still produce modest and continuous increases in intracellular $\mathrm{Ca}^{2+}$ and $\mathrm{pH}$. The use of specific inhibitors of $\mathrm{Ca}^{2+}$ channels and a detailed analysis of the patterns of $\mathrm{Ca}^{2+}$ uptake induced by the lowmolecular-mass sulfated fucan indicated that this derivative is not enough to open the first $\mathrm{Ca}^{2+}$ channel (characterized as voltage-dependent calcium channel), but it opens the second channel (characterized as store operated channel), at high concentrations (Hirohashi and Vacquier, 2002c). The increase of intracellular $\mathrm{Ca}^{2+}$ obtained by this low mass sulfated fucan induces exocytosis of the acrosomal vesicle, but only at slower kinetics, which are not able to induce a complete AR. A complete AR involves both the exocytosis of the acrosomal vesicle and the polymerization of the acrosomal process. In the incomplete AR, the vesicle undergoes exocytosis, but the actin is not polymerized to form the acrosomal process. This could result if there is not enough of an increase of intracellular $\mathrm{pH}$. The 
second $\mathrm{Ca}^{2+}$ channel responsible for the sustained calcium increase needed for the AR is known to be positively regulated by the increase in intracellular $\mathrm{pH}$ (Hirohashi and Vacquier, 2003).

\section{Two mechanisms of sperm-egg recognition in sea urchin fertilization}

We demonstrated that purified sulfated fucans from egg jelly induce the species-specific sperm AR. However, we had not investigated the contribution of this finding to the final biological event, that is, fertilization of the eggs. Furthermore, the relationship between the sulfated polysaccharide-based mechanism of sperm-egg recognition and the well-known bindin protein paradigm (Vacquier et al., 1995; Cameron et al., 1996; Glaser et al., 1999 , see the paper by Zigler in this issue) remained to be clarified.

At this stage we outlined an experimental approach to distinguish between the bindin- and the sulfated polysaccharide-based recognition mechanisms using three closely related sympatric Strongylocentrotus species (Biermann et al., 2004). Initially we determined fertilization among the species assessed by counting the proportions of fertilized eggs (Fig. 4A). For homologous (conspecific) gametes we observed a high percentage of successful fertilization, whereas heterospecific sperm fertilized only a small percentage of eggs. After inducing the AR with conspecific egg jelly, interspecific fertilization between Strongylocentrotus droebachiensis and Strongylocentrotus pallidus increased significantly in both directions. In contrast, the eggs of $S$. purpuratus could not be fertilized, even after the induction of the AR of the heterospecific
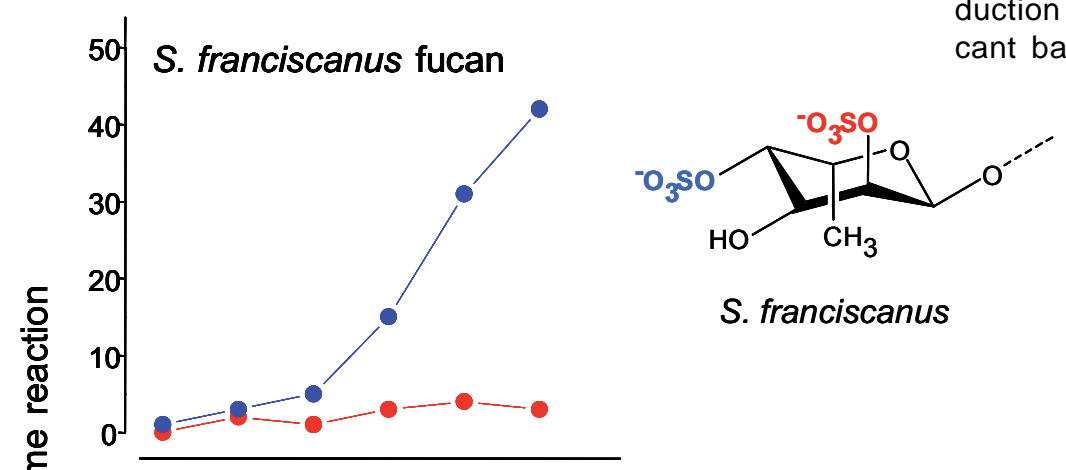

S. franciscanus

sperm with their conspecific egg jelly.

These observations indicated that induction of the AR by the egg jelly sulfated polysaccharides is the major limitation for interspecific fertilization between $\mathcal{S}$. droebachiensis and $\mathcal{S}$. pallidus (sulfated polysaccharide-based species recognition mechanism). In contrast, the major limitation for interspecific fertilization between $S$. purpuratus and the other two species is a step that follows the AR. Possibly this involves reaction of the protein bindin, exposed on the outside of the sperm acrosomal process, with its cognate egg membrane receptor (the bindin paradigm of species recognition). These two hierarchical steps in sea urchin gamete recognition are shown in Fig. 5.

To investigate whether failure of the sperm AR, induced by the egg jelly sulfated polysaccharides, is in fact the major limitation for interspecific fertilization between $\mathcal{S}$. droebachiensis and $\mathcal{S}$. pallidus, we determined the proportion of sperm that undergo the AR in response to egg jelly sulfated polysaccharide (Fig. 4B). S. droebachiensis sperm responded exclusively to the conspecific polysaccharide, whereas $S$. pallidus and $S$. purpuratus sperm cross-reacted. $\mathcal{S}$. droebachiensis contains a sulfated fucan with a structure unique among the other Strongylocentroid species examined, since it contains 4-linked instead of 3-linked fucose units. This sulfated fucan specifically triggered the AR only in sperm from its own species. Sperm from $S$. pallidus and $S$. purpuratus responded to conspecific and heterospecific 3-linked, but not to 4-linked sulfated fucans, independent of their sulfation patterns at the $0-2$ and $0-4$ positions.

In summary, we have shown that sulfated carbohydrate from egg jelly induces the AR species-specifically in S. droebachiensis and $S$. pallidus. This characterizes a sulfated polysaccharidebased species recognition mechanism involving signal transduction driving an exocytotic event. There are no other significant barriers to interspecific fertilization between these two species. In other Strongylocentroid species, the AR is triggered nonspecifically by heterogeneous egg jelly polysaccharides from the same genus, but exhibit species-specific sperm binding due to the protein bindin (the bindin paradigm of species recognition) (Fig. 5). In a previous study, Metz et al. (1994) compared fertilization between the species Echinometra

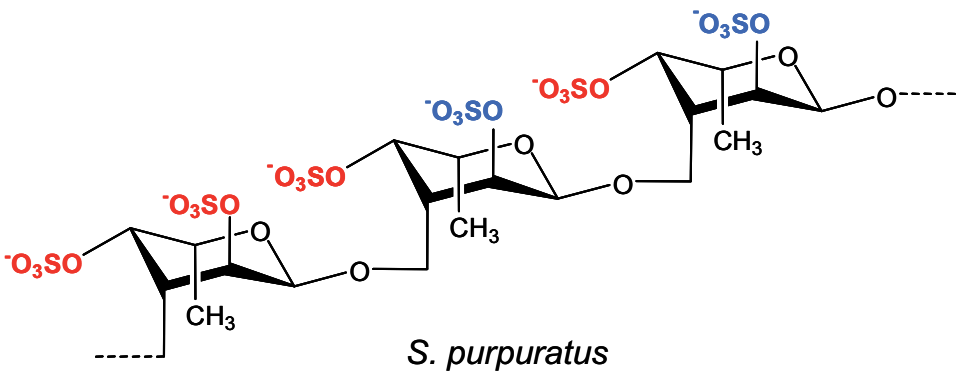

Fig. 3. Structures and effects of two sulfated fucans from two Strongylocentrotus species as inducers of the acrosome reaction of $\boldsymbol{S}$. purpuratus sperm. These species contain 3-linked fucans, which differ in the proportion of 2-and 4-sulfation (represented in red). Chemical oversulfation of these polysaccharides promotes the addition of sulfate esters at the 2- and 4-positions (represented in blue), the sole positions available for sulfation. Data modified from Hirohashi et al., 2002. 
A

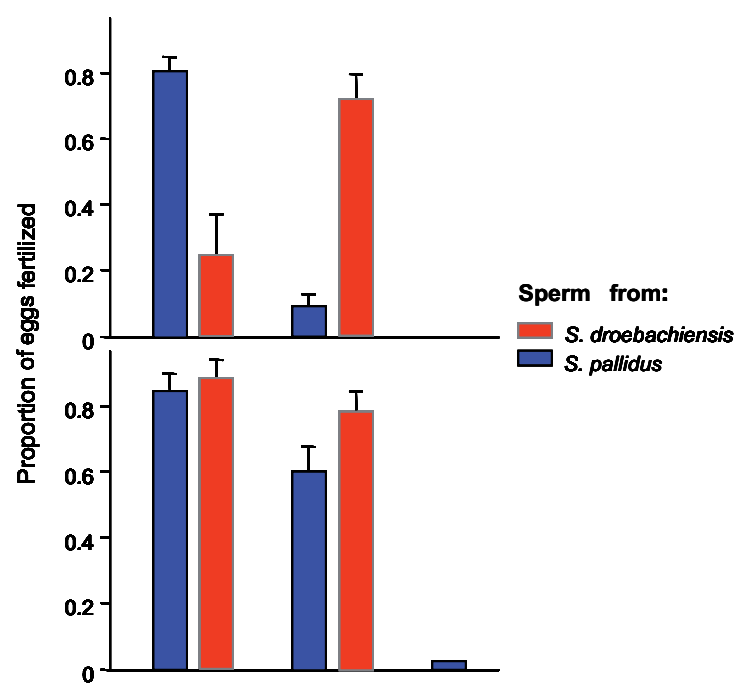

Eggs from: S. droebachiensis S. pallidus S. purpuratus

Fig. 4. Experimental approach to distinguish between the bindin and the sulfated polysaccharide-based mechanisms of sperm-egg recognition in sea urchin fertilization. (A) Fertilization success among three Strongylocentrotus species using sperm diluted in seawater (upper panel) and pre-reacted with conspecific egg jelly to induce the AR (lower panel). (B) Structures of sulfated fucans isolated from the egg jellies of sea urchins and their effects as inducers of the AR. The sulfated fucans were used at a concentration of $100 \mu \mathrm{g}$ of hexose $/ \mathrm{mL}$. Data modified from Biermann et al., 2004.

oblonga and $E$. mattheiand observed that the egg jelly of one species induces the AR perfectly in the sperm of the other species, but the reacted sperm can only bind to their own eggs. This indicates that for these two species the fertilization block is not $A R$ induction but the binding and fusion of the reacted sperm to the egg. This is an example of a bindin-based mechanism of species recognition.

\section{Isoforms of sulfated fucans}

Some species of sea urchins from the eastern north Pacific present two isotypes of sulfated fucan, which differ in their sulfation pattern. In the case of $S$. purpuratus one isoform has the repeating unit $\left[3-\alpha-L-F u c-2\left(S_{4}\right)-1\right]_{n}$, with some degree of 4-O-sulfation, while another is composed of the repeating oligosaccharide [3- $\alpha$-L-Fuc-2,4( $\left.\mathrm{SO}_{4}\right)-1 \rightarrow 3-\alpha-\mathrm{L}-\mathrm{Fuc}-4\left(\mathrm{SO}_{4}\right)-1 \rightarrow$ 3- $\alpha$-L-Fuc-4 $\left.\left(\mathrm{SO}_{4}\right)-1\right]_{n}$ (Alves et al., 1998). For the species $S$. droebachiensis, one isoform has a 4-linked tetrasaccharide repeating unit, while another isoform is composed of a single [4-

Fig. 5. Schematic representation of the two hierarchical steps in sea urchin gamete recognition. (a) Sulfated polysaccharide-based species recognition: the sperm acrosome reaction $(A R)$ is induced when a sperm with the correct receptor type contacts specific sulfated polysaccharide in the egg jelly coat (red triangles). This reaction exposes the protein bindin (shown in blue). (b) The bindin paradigm: the protein bindin, coating the outside of the acrosomal process, reacts with a matching egg membrane receptor. Reprinted from Biermann et al., 2004, with permission.

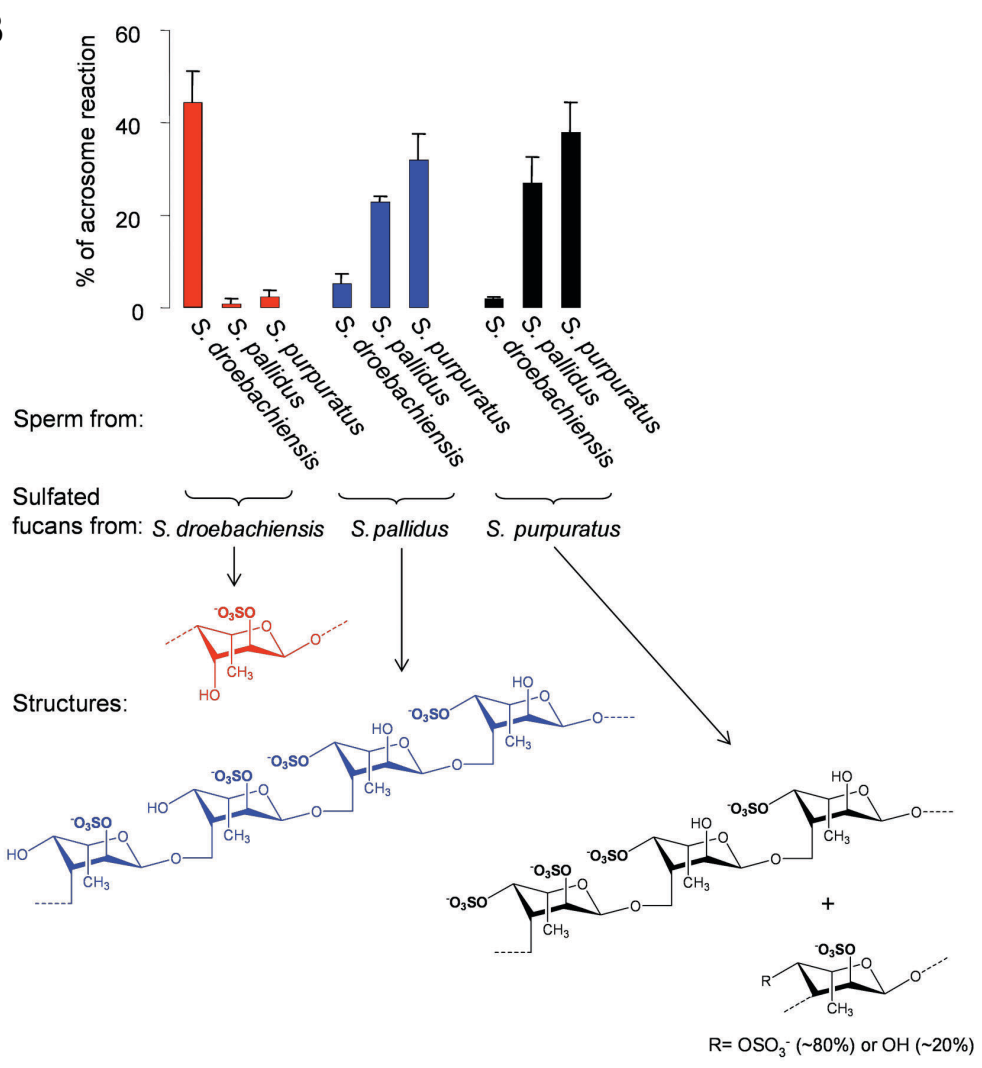

$\alpha$-L-Fuc-2 $\left(\mathrm{OSO}_{3}\right)$-1] unit (Vilela-Silva et al., 2002). In those cases, both isotypes have equivalent potency in inducing the $A R$ in homologous sperm and therefore are irrelevant under a physiological point of view. The biological significance of these isoforms is still unclear. They could represent differentiation within the species that might be a forerunner of incipient sympatric speciation.

The sea urchin L. variegatus also expresses two sulfated fucan isoforms. One is composed of the repeating tetrasaccharide $\left[3-\alpha-L-F u c-2\left(\mathrm{SO}_{4}\right)-1 \rightarrow 3-\alpha-L-F u c-4\left(\mathrm{SO}_{4}\right)-1 \rightarrow 3-\alpha-L-F u c-\right.$ $\left.2,4\left(\mathrm{SO}_{4}\right)-1 \rightarrow 3-\alpha-\mathrm{L}-\mathrm{Fuc}-2\left(\mathrm{SO}_{4}\right)-1\right]_{n}$ while another is composed exclusively of 4-sulfated and 3 -linked fucose units. In contrast

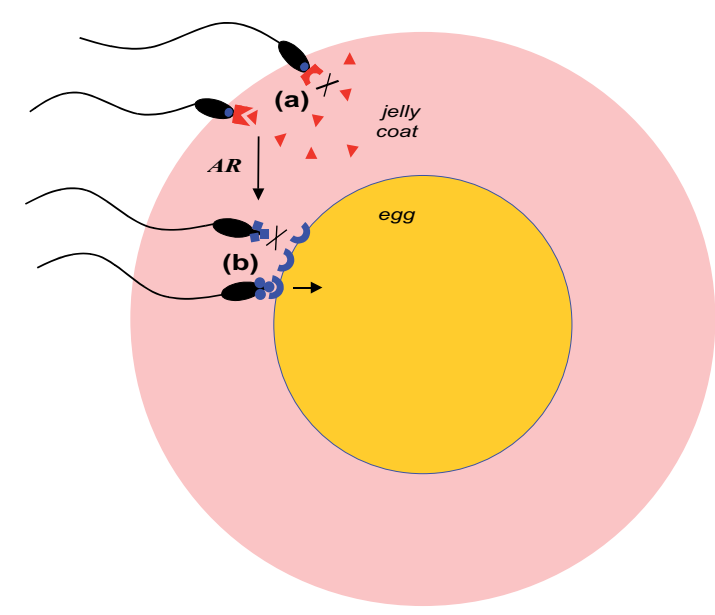


to the isoforms found in $S$. purpuratus and $S$. droebachiensis, those of $L$. variegatus differ dramatically in their capacity to induce AR in homologous sperm. Furthermore, in this species, expression of the fucan isotypes by females varies during different seasons of the year, and seems to be related to the periodicity of the reproductive cycle (Cinelli et al., 2007). The inactive isoform, which is composed of [3- $\alpha-\mathrm{L}-\mathrm{Fuc}-4\left(\mathrm{SO}_{4}\right)-1$ ] units, is expressed mostly during periods of low reproduction.

\section{Other molecules from the egg jelly also contribute to sea urchin fertilization}

Soluble egg jelly is a more potent $A R$ inducer than the purified sulfated fucan (Fig. 6A). Furthermore, several treatments of egg jelly, which affect components other than the sulfated polysaccharide, result in a $\sim 50 \%$ decrease in the AR activity (Shimizu et al., 1990, Keller and Vacquier, 1994). These observations indicate that other components in egg jelly, mostly sialoglycans and sperm-activating peptides, may potentiate the sulfated fucan's AR inducing activity.

The sialoglycans alone, or in the presence of the sulfated polysaccharide, do not increase intracellular $\mathrm{Ca}^{2+}$ (Fig. 6B), but clearly promote an increase in intracellular $\mathrm{pH}$ even in the absence of sulfated polysaccharide (Hirohashi and Vacquier, 2002d). An elevation of $\sim 0.25$ units in intracellular $\mathrm{pH}$ is crucial for the AR, triggering the polymerization of actin to form the acrosomal process. The change in intracellular $\mathrm{pH}$ produced by

A

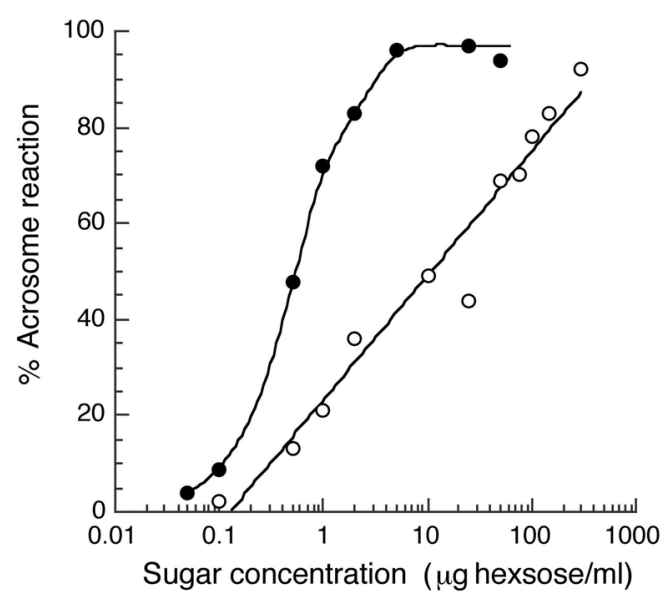

B

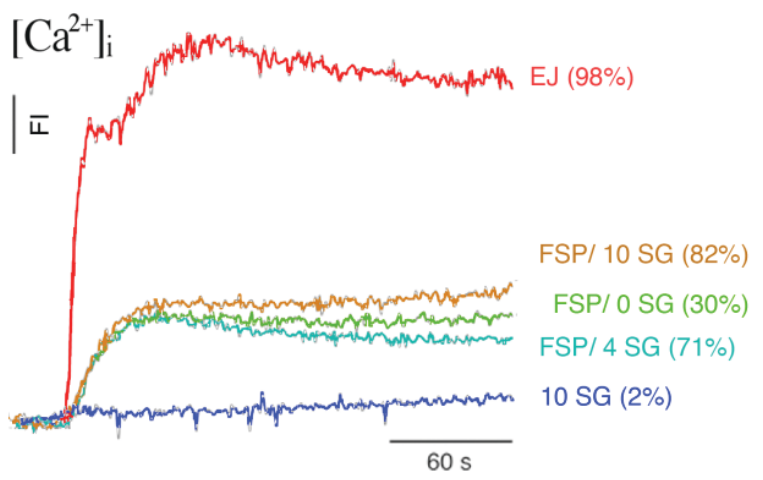

the sulfated polysaccharide is greater than that promoted by the sialoglycans alone and seems to depend upon the correct openning of sperm calcium channels. But the elevation of intracellular $\mathrm{pH}$ promoted by the sialoglycans is probably derived from a different pathway, as it is not inhibited by nifedipine or high extracellular $\mathrm{K}^{+}$, which block the first calcium channel (Fig. 6C). Probably, this property occurs through targeting the $\mathrm{Na}^{+} / \mathrm{K}^{+}$exchanger. The sialic acid residues of the sialoglycans are critical for this activity, as treatment with neuraminidase or mild oxidation with periodate abolishes the elevation of intracellular pH (Hirohashi and Vacquier, 2002d).

The sperm-activating peptides of sea urchin egg jelly contribute to fertilization through a distinct mechanism. These peptides diffuse away from the egg jelly and promote an activation of sperm metabolism and increase in flagellar motility (Shiba et al., 2005). Speract, the sperm-activating decapeptide from $S$. purpuratus, induces changes in intracellular $\mathrm{Ca}^{2+}, \mathrm{Na}^{+}$, cAMP, cGMP, and pH (Darszon et al., 2007). Its receptor is localized in the sperm tail (Cardullo et al., 1994) and the speract-induced increase of intracellular $\mathrm{Ca}^{2+}$ appears to initiate in the flagella and then spread to the sperm head (Wood et al., 2003). All these events favor efficient fertilization.

The role of the sperm activating peptides in AR induction is controversial. For some authors these peptides potentiate the effect of sulfated polysaccharide on the AR (Yamaguchi et al., 1989); while others indicate no contribution in AR (Schackmann and Chock, 1986). More recently, it has been shown that

C

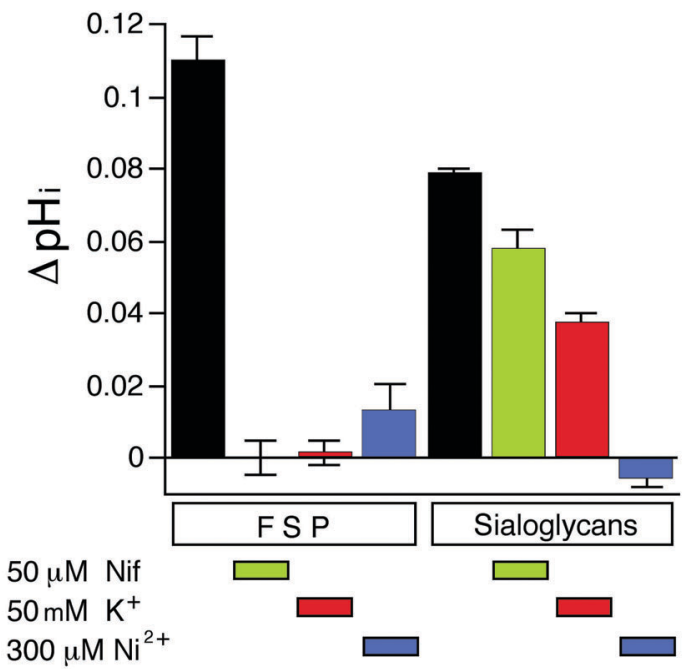

Fig. 6. Other components of the egg jelly potentiate the acrosome reaction. (A) The whole egg jelly $(E J, \bullet)$ is a better inducer of the AR than the purified sulfated fucan (FSP, O). Sperm were incubated with either EJ or FSP for 5 min in HEPES-sea water and scored for AR. (B) The sialoglycan (SG) alone, or in the presence of the FSP, does not cause an increase in the sperm intracellular $\mathrm{Ca}^{2+}$. The percentages indicated in the panel refer to AR activity obtained with the same concentrations of FSP and SG. (C) The sperm intracellular pH was measured in the presence of the sulfated fucan or the sialoglycan, in the absence and the presence of different calcium channel inhibitors such as nifedipine (Nif), high concentrations of extracellular $\mathrm{K}^{+}$and $\mathrm{Ni}^{2+}$. Nif blocks the opening of the first calcium channel, while $\mathrm{Ni}^{2+}$ blocks the second one. Reprinted from Hirohashi and Vacquier, 2002, with permission. 
Fig. 7. Phylogenetic relationship and divergence times of sea urchin species and a summary of the structure of the polysaccharides from their egg jelly. Data modified from Biermann et al., 2004. The sulfated polysaccharide-mediated mechanism of eggsperm recognition may have played a role in the separation of $\mathrm{S}$. droebachiensis from S. pallidus. The bindin mechanism may have functioned as an isolation mechanism on the earlier separation of the joint lineage from S. purpuratus. Experiments show that in Echinometra, the bindin bond of sperm to the egg is more important than AR induction (Metz et al., 1994), indicating a preponderance of the bindin mechanism of species differentiation.
Structure of the sulfated polysaccharides

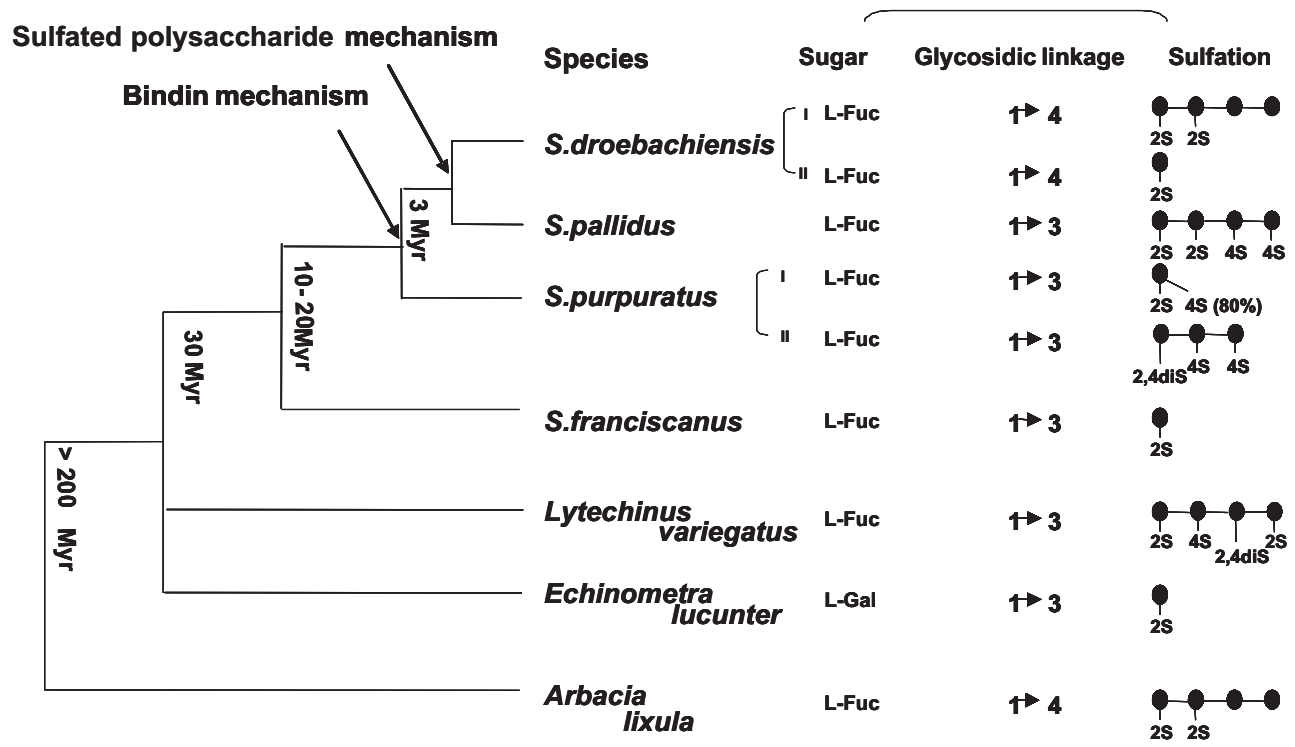

Myr = Million years of evolutionary divergence speract causes an elevation in intracellular $\mathrm{pH}$ and consequently functions as a positive cofactor, favoring the effect of sulfated polysaccharide on AR (Hirohashi and Vacquier, 2002b).

\section{A sperm receptor for sulfated fucan}

The action of sulfated polysaccharides as inducers of the sperm AR suggests the occurrence of a receptor in the sperm plasma membrane. The first indication of a receptor was achieved in S. purpuratus. A 210-kD sperm membrane glycoprotein, with homology to the human polycystic kidney disease protein, PKD1, was shown to bind species-specifically to the egg jelly dotted onto nitrocellulose (Podell and Vacquier 1984). This protein was later called "sea urchin receptor for egg jelly" (suREJ1; Moy et al., 1996). Monoclonal antibody to suREJ1 induces the AR and the antibody also competes with the sulfated fucan for binding the same inductive site on suREJ1 (Moy et al., 1996). Sequence analysis of REJ1 shows that it is a sperm membrane protein with two carbohydrate recognition domains. It localizes on the sperm tail and over the acrosomal vesicle and binds to the sulfated fucan in an affinity chromatography experiment (Vacquier and Moy, 1997).

In addition to REJ1, there are other potential receptors for the egg jelly sulfated polysaccharide. Of the 10 REJ proteins in the sea urchin genome, four are expressed on sperm (Gunaratne et al., 2007). suREJ2 is an intracellular plasma membrane protein and therefore not involved in the AR (Galindo et al., 2004). sUREJ4 is found exclusively in the sperm flagellar membrane (Gunaratne et al., 2007). suREJ3, which is structurally similar to REJ4, localizes on the sperm membrane only over the acrosomal vesicle and possesses a C-terminal transmembrane region that is homologous to voltage-dependent $\mathrm{Ca}^{2+}$ channels (Mengerink et al., 2002). Although suREJ3 could be possibly correlated to a signaling transduction event as the $A R$, there is no evidence that
sUREJ3 serves as the receptor for sulfated fucan. suREJ3 is complexed with sea urchin PKD2, and in mammals PKD2 is known to form a nonspecific cation channel carrying calcium and sodium ions (Neill et al., 2004) Like suREJ3, PKD2 is only located in the plasma membrane over the acrosomal vesicle. Other molecules present in the egg jelly, which contribute to potentiation of the AR, could interact with the REJ3/PKD2 complex.

\section{Sulfated fucans: another avenue for sea urchin specia- tion?}

Phylogenetic relationships and species divergence times of sea urchins and a summary of the structure of the polysaccharides from their egg jellies are shown in Fig. 7. These observations indicate that the genes involved in the biosynthesis of the sulfated fucans did not evolve in concordance with evolutionary distance, but underwent a dramatic change near the tip of the Strongylocentrotid tree. The AR specificity could have played a role in establishing the prezygotic reproductive isolation that gave rise to these species. There is evidence that $S$. droebachiensis and $S$. pallidus separated from $S$. purpuratus before their divergence from each other. The bindin mechanism may have functioned as an isolation mechanism in the earlier separation of the lineage from $S$. purpuratus. A later speciation event originated the species $S$. droebachiensis and S. pallidus, possibly due to incompatibility of the sulfated fucans and AR induction (sulfated polysaccharide-based mechanism).

Surprisingly, the egg jelly of $S$. droebachiensis contains a 4linked sulfated fucan clearly distinct from those of the two closely related congeneric species. However, Arbacia lixula, that diverged from Strongylocentrotus 200 million years ago, also has a 4 -linked fucan. This similarity in glycosidic bonding among fucosyl residues could be due to convergent evolution. The occurrence of the same sulfated fucan in these two very distantly related species 
is not relevant for their cross-fertilization, because the populations of $A$. lixula and $S$. droebachiensis do not overlap geographically. Nevertheless, this observation suggests that the gene for the biosynthesis of 4-linked fucan may have been retained during evolution of $\mathcal{S}$. droebachiensis, but remained repressed or nonexpressed until a period of strong natural selection. This observation reminds us of a general concept on evolution, stating that "the past of an organism not only determines its future but also gives an enormous reserve for a rapid modification, based on little genetic changes" (Gould, 1984).

\section{Conclusions and challenges}

Our work on the structural characterization of sea urchin sulfated polysaccharides led us to the discovery of unique polymers in these organisms. These polysaccharides have simple, linear structures, composed of repeating units of oligosaccharides. They differ among the various species of sea urchins in specific patterns of sulfation, the glycosidic linkage within their repeating units and in the type of monosaccharide. These polysaccharides show species-specificity in inducing the AR, providing a clear example of a biological transduction event regulated by a sulfated polysaccharide. This distinct sulfated polysaccharidemediated mechanism for cell-cell recognition during fertilization co-exists with the sperm bindin recognition of its egg receptor.

The major challenge at this stage is the identification of the metabolic pathways involved in the biosynthesis of the egg jelly polysaccharides. This is not only a fascinating challenge for carbohydrate research, but may also help to define the genetic basis for the carbohydrate mechanism of species recognition.

\section{Acknowledgments}

We are grateful to the contributions to this work by A.P. Alves, B. Mulloy, A.P. Valente, V.D. Vacquier and C.H. Biermann. The work at the Federal University of Rio de Janeiro was supported by grants from Conselho Nacionalde Desenvolvimento Científico e Tecnológico (CNPq), Fundação de Amparo à Pesquisa do Estado do Rio de Janeiro (FAPERJ) and International Foundation for Science (IFS, for Ana Cristina E.S. de Vilela-Silva).

\section{References}

ALVES, A.P., MULLOY, B., DINIZ, J.A. and MOURÃO, P.A.S. (1997). Sulfated polysaccharides from the egg jelly layer are species-specific inducers of acrosomal reaction in sperms of sea urchins. J Biol Chem 272: 6965-6971.

ALVES, A.P., MULLOY, B., MOY, G.W., VACQUIER, V.D. and MOURÃO P.A.S. (1998). Females of the sea urchin Strongylocentrotus purpuratus differ in the structures of their egg jelly sulfated fucans. Glycobiology 8: 939-946.

BECKER, C.F., GUIMARÃES, J.A., MOURÃO, P.A.S. and VERLI, H. (2007) Conformation of sulfated galactan and sulfated fucan in aqueous solutions: Implications to their anticoagulant activities. J. Mol Graph Mode/26: 391-399.

BERTEAU, O. and MULLOY, B. (2003). Sulfated fucans, fresh perspectives: structures, functions, and biological properties of sulfated fucans and an overview of enzymes active toward this class of polysaccharide. Glycobiology 13: 29R-40R

BIERMANN, C.H., MARKS, J.A., VILELA-SILVA, A.C.E.S., CASTRO, M.O. and MOURÃO, P.A.S. (2004). Carbohydrate-based species recognition in sea urchin fertilization: another avenue for speciation? Evol. and Develop 6: 353361.

CAMERON, R.A., WALKUP, T.S., ROOD, K., MOORE, J.G. and DAVIDSON, E.H. (1996). Specific in vitro interaction between recombinant Strongylocentrotus purpuratus bindin and a recombinant $45 \mathrm{~A}$ fragment of the putative bindin receptor. Dev. Biol. 180: 348-352.

CARDULLO, R.A., HERRICK, S.B., PETERSON, M.J. and DANGOTT, L.J. (1994). Speract receptors are localized on sea urchin sperm flagella using a fluorescent peptide analog. Dev Bio/162(2):600-7.

CINELLI, L.P., CASTRO, M.O., SANTOS, L.L., GARCIA, C.R., VILELA-SILVA, A.C.E.S. and MOURÃO, P.A.S. (2007). Expression of two different sulfated fucans by females of $\angle$ ytechinus variegatus may regulate the seasonal variation in the fertilization of the sea urchin. Glycobiology 17(8):877-85.

COUCHMAN, J.R., CHEN, L. and WOODS, A. (2001). Syndecans and cell adhesion. Int Rev Cyto/207:113-50.

DARSZON, A., TREVIÑO, C.L., WOOD, C., GALINDO, B., RODRÍGUEZ-MIRANDA E., ACEVEDO, J.J., HERNANDEZ-GONZÁLEZ, E.O., BELTRÁN, C. MARTÍNEZ-LÓPEZ, P. and NISHIGAKI, T. (2007). Ion channels in sperm motility and capacitation. Soc Reprod Fertil Supp/65:229-44.

DIEKMAN, A.B. (2003). Glycoconjugates in sperm function and gamete interac tions: how much sugar does it take to sweet-talk the egg? Cell Mol Life Sci 60(2):298-308.

GALINDO, B.E., MOY, G.W. and VACQUIER, V.D. (2004). A third sea urchin sperm receptor for egg jelly module protein, suREJ2, concentrates in the plasma membrane over the sperm mitochondrion. Dev Growth Differ 46:53-60.

GLASER, R.W., GRUNE, M., WANDELT, C. and ULRICH, A.S. (1999). Structure analysis of a fusogenic peptide sequence from the sea urchin fertilization protein bindin. Biochemistry 38: 2560-2569.

GOULD, S.J. (1984). Hen's teeth and house's toes. Further reflections in natural history. Penguin, London.

GUNARATNE, H.J., MOY, G.W., KINUKAWA, M., MIYATA, S., MAH, S.A. and VACQUIER, V.D. (2007). The 10 sea urchin receptor for egg jelly proteins (SpREJ) are members of the polycystic kidney disease-1 (PKD1) family. BMC Genomics 8:235

HIROHASHI, N., VILELA-SILVA, A.C.E.S., MOURÃO, P.A.S. and VACQUIER, V.D. (2002a). Structural requirements for species-specific induction of the sperm acrosome reaction by sea urchin egg sulfated fucan. Biochem Biophys Res Commun 298: 403-407

HIROHASHI, N. and VACQUIER, V.D. (2002b). Egg fucose sulfate polymer, sialoglycan, and speract all trigger the sea urchin sperm acrosome reaction. Biochem Biophys Res Commun 296: 833-839.

HIROHASHI, N. and VACQUIER, V.D. (2002c). High molecular mass egg fucose sulfate polymer is required for opening both $\mathrm{Ca} 2+$ channels involved in triggering the sea urchin sperm acrosome reaction. J Biol Chem 277: 1182-1189.

HIROHASHI, N. and VACQUIER, V.D. (2002d). Egg sialoglycans increase intracellular $\mathrm{pH}$ and potentiate the acrosome reaction of sea urchin sperm. $J$ Biol Chem 277:8041-8047

HIROHASHI, N. and VACQUIER, V.D. (2003). Store-operated calcium channels trigger exocytosis of the sea urchin sperm acrosomal vesicle. Biochem Biophys Res Commun 304:285-292.

HOSHI, M., NISHIGAKI, T., USHIYAMA, A., OKINAGA, T., CHIBA, K. and MATSUMOTO, M. (1994). Egg-jelly signal molecules for triggering the acrosome reaction in starfish spermatozoa. Int $J$ Dev Bio/38:167-174.

KAMEI, N. and GLABE, C.G. (2003). The species-specific egg receptor for sea urchin sperm adhesion is EBR1, a novel ADAMTS protein. Genes and development 17: 2502-2507.

KELLER, S.H. and VACQUIER, V.D. (1994). The isolation of acrosome-reactioninducing glycoproteins from sea urchin egg jelly. Dev Biol162(1):304-12

MENGERINK, K.J., MOY, G.W. AND VACQUIER, V.D. (2002). suREJ3, a polycystin1 protein, is cleaved at the GPS domain and localizes to the acrosomal region of sea urchin sperm. J Biol Chem 277(2):943-8.

METZ, E.C., KANE, R.E., YANAGIMACHI, H. and PALUMBI, S.R. (1994) Fertilization between closely related sea urchins is blocked by incompatibilities during sperm-egg attachment and early stages of fusion. Biol Bull 187:23-34.

MILLER, D.J. and AX, R.L. (1990). Carbohydrates and fertilization in animals. Mol Reprod Dev 26(2):184-98.

MINOR, J.E., FROMSON, D.R., BRITTEN, R.J. and DAVIDSON, E.H. (1991) Comparison of the bindin proteins of Strongylocentrotus franciscanus, $S$. purpuratus, and Lytechinus variegatus: sequences involved in the species specificity of fertilization. Mol Biol Evo/8:781-95 
MOURÃO, P.A.S. (2004). Use of sulfated fucans as anticoagulant and antithrombotic agents: future perspectives. Current Pharmaceutical Design 10: 967-981.

MOY, G.W., MENDOZA, L.M., SCHULZ, J.R., SWANSON, W.J., GLABE, C.G. and VACQUIER, V.D. (1996). The sea urchin sperm receptor for egg jelly is a modular protein with extensive homology to the human polycystic kidney disease protein, PKD1. J Cell Bio/133(4):809-17.

MOY, G.W. and VACQUIER, V.D. (1979). Immunoperoxidase localization of bindin during the adhesion of sperm to sea urchin egg. Curr Top Dev Bio/13:31-44.

MULLOY, B., RIBEIRO, A.C., ALVES, A.P., VIEIRA, R.P. and MOURÃO, P.A.S. (1994). Sulfated fucans from echinoderms have a regular tetrasaccharide repeating unit defined by specific patterns of sulfation at the $0-2$ and $0-4$ positions. J Biol Chem 269: 22113-22123.

NEILL, A.T., MOY, G.W. and VACQUIER, V.D. (2004) Polycystin-2 associates with the polycystin-1 homolog, suREJ3, and localizes to the acrosomal region of sea urchin spermatozoa. Mol Reprod Dev67:472-7.

PODELL, S.B. AND VACQUIER, V.D. (1984). Wheat germ agglutinin blocks the acrosome reaction in Strongylocentrotus purpuratus sperm by binding a 210.000mol-wt membrane protein. J Cell Bio/99:1598-1604.

SCHACKMANN, R.W. and CHOCK, P.B. (1986). Alteration of intracellular [ $\left.\mathrm{Ca}^{2+}\right]$ in sea urchin sperm by the egg peptide speract. Evidence that increased intracellular $\left[\mathrm{Ca}^{2+}\right]$ is coupled to $\mathrm{Na}^{+}$entry and increased intracellular $\mathrm{pH}$. J Biol Chem 261: 8719-8728.

SEGALL, G.K. and LENNARZ, W.J. (1979). Chemical characterization of the component of the jelly coat from sea urchin eggs responsible for induction of the acrosome reaction. Dev Bio/71(1):33-48.

SELVA, E.M. and PERRIMON, N. (2001). Role of heparan sulfate proteoglycans in cell signaling and cancer. Adv Cancer Res 83:67-80.

SHIBA, K., OHMURO, J., MOGAMI, Y., NISHIGAKI, T., WOOD, C.D., DARSZON, A., TATSU, Y., YUMOTO, N. and BABA, S.A. (2005). Sperm-activating peptide induces asymmetric flagellar bending in sea urchin sperm. Zoolog Sci22(3):293-9.
SHIMIZU, T., KINOH, H., YAMAGUCHI, M., and SUZUKI, N. (1990). Purification and characterization of the egg jelly macromolecules sialoglycoprotein and fucose sulfate glycoconjugate of the sea urchin Hemicentrotus pulcherrimus. Develop. Growth Differ32: 473-487.

VACQUIER, V.D. and MOY, G.W. (1997). The fucose sulfate polymer of egg jelly binds to sperm REJ and is the inducer of the sea urchin sperm acrosome reaction. Dev Bio/192(1):125-35

VACQUIER, V.D., SWANSON, W.J. and HELLBERG, M.E. (1995). What have we learned about sea urchin sperm bindin? Developmental, Growth and Differentiation 37:1-10.

VASSEUR, E. (1948). Chemical studies on the jelly coat of the sea urchin egg. Acta Chem Scand 2:900-913.

VILELA-SILVA, A.C.E.S., ALVES, A.P., VALENTE, A.P., VACQUIER, V.D. and MOURÃO, P.A.S. (1999). Structure of the sulfated alpha-1-fucan from the egg jelly coat of the sea urchin Strongylocentrotus franciscanus: patterns of preferential 2-O and 4-O-sulfation determine sperm cell recognition. Glycobiology 9: 927-933.

VILELA-SILVA, A.C.E.S., CASTRO, M.O., VALENTE, A.P., BIERMANN, C.H. and MOURÃO, P.A.S. (2002). Sulfated fucans from the egg jellies of the closely related sea urchins Strongylocentrotus droebachiensis and Strongylocentrotus pallidus ensure species-specific fertilization. J Biol Chem 277: 379-387.

WALKER, C.W., UNUMA, T., MCGINN, N.A., HARRINGTON, L.M. and LESSER, M.P. (2001). Reproduction of sea urchins. In: Edible Sea Urchins: Biology and Ecology, J.M. Lawrence, ed. Amsterdam, Elsevier. p. 5-26.

WOOD, C.D., DARSZON, A. and WHITAKER, M. (2003). Speract induces calcium oscillations in the sperm tail. J Cel/ Bio/161(1):89-101.

YAMAGUCHI, M., KURITA, M. and SUZUKI, N. (1989). Induction of the acrosome reaction of Hemicentrotus pulcherrimus spermatozoa by the egg jelly molecules, fucose-rich glycoconjugate and sperm-activating peptide I. Dev Growth Differ 31: 233-239. 


\section{Related, previously published Int. J. Dev. Biol. articles}

See our recent Special Issue Developmental Biology in Poland edited by Tarkowski, Maleszewski and Kloc at: http://www.ijdb.ehu.es/web/contents.php?vol=52\&issue=2-3

See our recent Special Issue Ear Development edited by Fernando Giraldez and Bernd Fritzsch at: http://www.ijdb.ehu.es/web/contents.php?vol=51\&issue=6-7

See our Special Issue Evolution and Development edited by Jordi Baguna and Jordi Garcia-Fernandez at: http://www.ijdb.ehu.es/web/contents.php?vol=47\&issue=7-8

X-epilectin: a novel epidermal fucolectin regulated by BMP signalling Karine Massé, Rebecca Baldwin, Mark W. Barnett and Elizabeth A. Jones Int. J. Dev. Biol. (2004) 48: 1119-1129

Ca2+-independent protein kinase $\mathbf{C}$ signalling in mouse eggs during the early phases of fertilization. Carla Tatone, Simona Delle Monache, Antonella Francione, Luisa Gioia, Barbara Barboni and Rosella Colonna Int. J. Dev. Biol. (2003) 47: 327-333

Distinct mechanisms underlie sperm-induced and protease-induced oolemma block to sperm penetration. Sebastian Komorowski, Katarzyna Szczepanska and Marek Maleszewski Int. J. Dev. Biol. (2003) 47: 65-69

Heparan sulfates isolated from adult neural progenitor cells can direct phenotypic maturation. Hiram Chipperfield, Kuldip S Bedi, Simon M Cool and Victor Nurcombe Int. J. Dev. Biol. (2002) 46: 661-670

Developmental roles of heparan sulfate proteoglycans: a comparative review in Drosophila, mouse and human. Marc Princivalle and Ariane de Agostini Int. J. Dev. Biol. (2002) 46: 267-278

Association of egg zona pellucida glycoprotein mZP3 with sperm protein sp56 during fertilization in mice. $\mathrm{N}$ Cohen and P M Wassarman

Int. J. Dev. Biol. (2001) 45: 569-576

Sperm-egg interaction at fertilization: glycans as recognition signals. F Rosati, A Capone, C D Giovampaola, C Brettoni and R Focarelli Int. J. Dev. Biol. (2000) 44: 609-618

Fertilization triggers activation of Fyn kinase in the zebrafish egg. W Wu and W H Kinsey Int. J. Dev. Biol. (2000) 44: 837-841

Egg-jelly signal molecules for triggering the acrosome reaction in starfish spermatozoa.

M Hoshi, T Nishigaki, A Ushiyama, T Okinaga, K Chiba and M Matsumoto Int. J. Dev. Biol. (1994) 38: 167-174

Mechanisms of initiation and propagation of the calcium wave during fertilization in deuterostomes.

F Berger

Int. J. Dev. Biol. (1993) 37: 245-262

Calcium in sea urchin egg during fertilization.

I Gillot, P Payan, J P Girard and C Sardet

Int. J. Dev. Biol. (1990) 34: 117-125

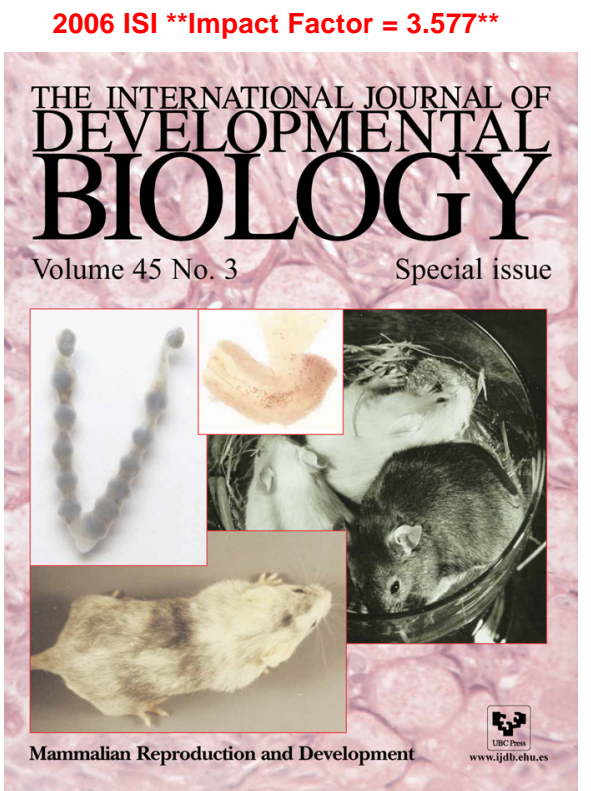

